\title{
WZORY KULTURY GOSPODARCZEJ \\ JAKO PRZEDMIOT BADANIA. KILKA UWAG PO LEKTURZE STOSUNKÓW PRACY... JANUSZA HRYNIEWICZA
}

\begin{abstract}
Rotengruber Przemysław, Wzory kultury gospodarczej jako przedmiot badania. Kilka uwag po lekturze Stosunków pracy... Janusza Hryniewicza [The patterns of economic culture as a subject of study. A few comments after reading Janusz Hryniewicz] edited by W. Banach - "Człowiek i Społeczeństwo", vol. XXXVIII, Poznań 2014, pp. 33-48, Adam Mickiewicz University Press. ISBN 978-83-232-2791-5. ISSN 0239-3271.

The patterns of culture is a well known phrase which was used for first time by Ruth Benedict. The successors of this tradition believe that culture - in its essence - is governed by rules of a different kind. Anthropologists, sociologists and representatives of cultural studies, focus attention on patterns of very long duration (long-term historical structures which denote a variety of organized behaviours). One of these researchers is Janusz Hryniewicz. According to Hryniewicz, Polish economic practice is deeply involved in the cultural patterns of a so called manor farm origin. Unfortunately, this statement is inefficiently justified. This assumption is supported by circumstancial evidence (similarities between historical events) instead of the proper structural analysis of historical data. The main purpose of this paper is to scrutinize how patterns of culture (especially patterns of Polish economic culture) arise and which factors determine their stability.
\end{abstract}

Przemysław Rotengruber, Uniwersytet im. Adama Mickiewicza w Poznaniu, Wydział Nauk Społecznych, Instytut Kulturoznawstwa, Zakład Etyki Gospodarczej, ul. Szamarzewskiego 89a, 60-568 Poznań, Poland.

\section{WSTĘP}

Podejmowane od niepamiętnych czasów próby zapanowania nad gospodarczym żywiołem napotykają powtarzające się przeszkody. Żywioł ów w stopniu ograniczonym poddaje się systematyzacji. Przekonujemy się o tym zwłaszcza wtedy, gdy - stawiając czoła wyzwaniom powszednim - odkrywamy niespójności $\mathrm{w}$ systemie wiedzy o mechanizmie reprodukcji mate- 
rialnej. Odnosząc rzecz do Ksenofonta i Arystotelesa rozważań dotyczących norm obowiązujących w przestrzeni własnego domostwa (oikonomos), wątpliwości wywołują zarówno owe normy, jak i społeczne otoczenie domostwa skłaniające gospodarza do przyjęcia postawy odzwierciedlającej preferowane przez nie reguły postępowania. Warunkiem poprawności wyboru jest - $\mathrm{w}$ tej optyce - uwzględnienie konkurencyjnych aksjologii $\mathrm{w}$ powszednich realiach reprezentowanych przez określone wzorce kultury. Zależność łączącą projekt zarządczy z wiedzą o kulturze gospodarczej wykorzystuje Janusz Hryniewicz. W książce zatytułowanej Stosunki pracy w polskich organi$z_{a c j a c h}{ }^{1}$ czyni z niej podstawowy schemat wyjaśniający. Prezentację preferowanych modeli motywacyjnych oraz stylów kierowania przedsiębiorstwem poprzedza rekonstrukcją obyczajów gospodarczych, kształtujących się w Polsce od XVI wieku. Hryniewicz - podobnie jak Fons Trompenaars czy Geert Hofstede - stoi na stanowisku, że bez uwzględnienia determinant kulturowych model ekonomiczny pozostaje bezużytecznym narzędziem. Skądinąd trafne, założenie wywołuje tymczasem obawy dotyczące jego wystarczalności. Spośród nich trzy zasługują na szczególną uwagę. Po pierwsze, zadanie utrudnia różnorodność norm i dyrektyw współtworzących obraz kultury, także kultury gospodarczej. Heteronomia, o której mowa, zmusza podmiot poszukujący formuły porządkującej do dokonywania arbitralnych wyborów pomiędzy tym, co esencjalnie ważne, a tym, co ważne akcydentalnie. Obraz całości osiąga spójną całość kosztem pomyłek polegających na błędnym odczytaniu bądź przeakcentowaniu znaczenia wybranych reguł postępowania. Zależności przykuwające uwagę badacza przesłaniają mu to, co kształtuje zachowania społeczne na poziomie głębokim². Drugą przeszkodą są zatory poznawcze wynikające z przynależności użytkownika wzorów kultury do określonej wspólnoty interpretacji. Ta sama norma w przypadku konfliktu interesów dzielącego jej użytkowników może otrzymywać diametralnie różne znaczenie. Gdy przedmiotem badania stają się dyrektywy regulujące zachowanie uczestników sfery publicznej, o powodzeniu przedsięwzięcia decyduje nie tylko ustalenie ich pochodzenia, lecz przede wszystkim znajomość aktorów - tu i teraz - wcielających się $\mathrm{w}$ rolę ich kulturowego transmitera ${ }^{3}$. To oni przecież nadają znaczenie owym treściom. Po trzecie, należy przypomnieć, że skonfliktowanych akto-

${ }^{1}$ J.T. Hryniewicz, Stosunki pracy $w$ polskich organizacjach, Wydawnictwo Naukowe Scholar, Warszawa 2007.

2 R.K. Merton, Teoria socjologiczna i struktura społeczna, przeł. E. Morawska, J. Wertenstein-Żuławski, PWN, Warszawa 1982, s. 92-150; E. Hankiss, Pułapki społeczne, przeł. T. Kulisiewicz, Wiedza Powszechna, Warszawa 1986, s. 109-110.

${ }^{3}$ R. Putnam, The Prosperous Community: Social Capital and Public Life, TAP, Spring 1993, s. 168. 
rów dzieli nie tylko interes. W równym stopniu szkodzą im braki kompetencyjne i zaniechania komunikacyjne. Te przeszkody można likwidować, mówiąc w największym skrócie, angażując się w proces edukacji - zwłaszcza edukacji obywatelskiej - społecznych interlokutorów. Stereotypy, urazy, przesądy uchodzące za nieprzezwyciężalne mogą tracić na znaczeniu wraz ze zmianą okoliczności. Próżno szukać dziś polityków dekadę temu manifestujących swoją niechęć do Unii Europejskiej. Próżno ich szukać, pomimo że od 2008 roku Unia zmaga się z kryzysem gospodarczym. Miejsce niedawnych obaw zajęły marzenia - uboższych zwłaszcza - społeczności lokalnych, by na ich terenie pojawiali się „poważni inwestorzy zachodni”.

Wymienione ograniczenia mają trwały charakter. Ich pominięcie - choćby nieumyślne - przekłada się na jakość sprawozdania dotyczącego wzorów kultury. Jeśli dodać do tego, że ma ono służyć naprawie rzeczywistości społecznej - względnie korekcie jej wybranych fragmentów - wówczas sprawa wykracza poza ramy akademickie. Mając to na względzie, zamierzam skonfrontować zebrane przesłanki badawcze z koncepcją J. Hryniewicza, odtworzyć związki łączące poprawnie gromadzoną wiedzę sprawozdawczą z projektem stanu pożądanego, wreszcie sformułować konkurencyjne hipotezy dotyczące warunków badania wzorców kultury gospodarczej. Cel wydaje się oczywisty. Rzecz w tym, by ostrożnie przyjmować odpowiedzi na pytanie o to, co nam się przydarza - zwłaszcza odpowiedzi aspirujące do miana wyjaśnień kompleksowych.

\section{KULTURA JAKO KONGLOMERAT WZORCÓW}

Położenie akcentu na historycznie utrwalone wzorce postępowania wiedzie do następującej wątpliwości. Postulatowi badań nad kulturą - powtarzanemu w różnych kontekstach teoretycznych - rzadko towarzyszą wyjaśnienia obejmujące jej cechy definicyjne. Należy podkreślić, że nie chodzi tu o „wariacje na temat kultury” jako zbioru reguł różnej treści i różnego pochodzenia. O użyteczności formuły porządkującej decyduje właściwe uchwycenie związków łączących owo pojęcie z pryncypium społecznej ciągłości oraz mechanizmem społecznej zmiany.

Można ułatwić sobie zadanie, rezygnując z cezury oddzielającej świat kultury od świata społecznego. Ma to jednak swoje konsekwencje. Podobna redukcja skutkuje tym, że kultura zatraca cechy swoiste, czyniące z niej depozyt wartości autonomicznych. Owszem, znikają obawy dotyczące miarodajności wglądu w przedmiot badania. Nie znika natomiast problem. Poza normami stanowionymi przez społeczeństwo uwzględnienia wymagają 
wzorce potwierdzające istnienie czegoś, na co nie ma ono bezpośredniego wpływu - niekiedy wzorce, które jego członkowie, działając w refleksyjnym nastawieniu, uznaliby za niezgodne z ich własnym interesem. Gnuśny rzemieślnik, poza czasem i pieniędzmi, traci zaufanie społecznego otoczenia. Handlowiec wytwarzający zależność konfrontacyjną z klientami jest przez nich bojkotowany bądź okradany. Te przykłady można mnożyć. Wynika z nich, że korekta złych obyczajów względnie naprawa społeczeństwa padającego ofiarą własnych przekonań wymagają dostępu do wiedzy o heterogenicznych systemach wartości współtworzących obraz kultury.

Uznanie autonomii świata kultury wobec świata społecznego jest potrzebne. Wprowadza w ustalenia dotyczące społecznej zmiany element nieprzewidywalności będący następstwem wyrwania jednostki z objęć społeczeństwa (przynajmniej $\mathrm{w}$ takim stopniu, $\mathrm{w}$ jakim jest ona $\mathrm{w}$ stanie przeciwstawić społecznej normie inne reguły postępowania). Jednocześnie to rozstrzygnięcie pociąga za sobą trudności. Najpierw na badacza spada obowiązek uzasadnienia tezy o aksjologicznej odrębności świata kultury wobec świata społecznego. Następnie musi on znaleźć sposób badania uwzględniający ustanowioną dystynkcję. Skoro świat kultury rządzi się własnymi prawami, to wgląd w jego treści wymaga albo zastosowania odrębnego narzędzia, albo wykazania, że metody służące objaśnianiu "faktów społecznych" w równym stopniu nadają się do tego, by za ich pomocą wdrażać "procedurę rozumienia" całych formacji dziejowych.

Metodologiczny dylemat, rzec by można, spycha badacza do narożnika. Zanim zacznie on mówić o prawach rządzących rzeczywistością kulturową, musi uczynić wiele, by jego sprawozdanie stało się czymś więcej niż tylko wyrazem jego własnych (subiektywnie pojętych) przekonań. Nie jest jednak bezsilny. Jego punktem zaczepienia, problemem inicjującym badanie, są wydarzenia i procesy, doniosłość których potwierdzają historycy. W ten sposób badacz dociera do konglomeratu treści odtworzonych za pomocą wiedzy o faktach, niekiedy faktach zamierzchłych. Jest o krok dalej. Otrzymuje obraz formacji kulturowej - poprzez wybory powszednie podejmowane przez jej uczestników - potwierdzającej swoje przywiązanie do określonych wartości bądź ideałów. Rzecz w tym, że owe wartości nie komponują się spontanicznie. Nie tworzą poznawczo dostępnych całości ${ }^{4}$. Dlatego poszukiwanie ładu aksjologicznego $\mathrm{w}$ projekcie zakładającym ich kompleksowo pojętą hierarchizację jest przedsięwzięciem trudnym, wręcz niemożliwym. $\mathrm{W}$ tworzeniu podwalin kultury Zachodu nie mniej doniosłą rolę odegrali

${ }^{4}$ F. Znaniecki, Pisma filozoficzne, t. 1, przeł. J. Wocial, PWN, Warszawa 1987, s. 151, 172-183; J. Wocial, Znanieckiego filozofia wartości, [w:] F. Znaniecki, op. cit., s. LXXXII. 
Sokrates, Abelard czy Ryszard Lwie Serce niż Jezus i Święci Pańscy. Tak to działa!

Badania nad kulturą i jej artefaktami podejmuje Janusz Hryniewicz ${ }^{5}$. Przedmiotem jego zainteresowania są staropolskie wzorce organizacyjne. Hryniewicz wykorzystuje dane gromadzone przez historyków, by za ich pomocą odtworzyć mechanizm rywalizacji i współdziałania gospodarczych interlokutorów. Powstanie Rzeczypospolitej Obojga Narodów (1569 r.) zbiegło się w czasie z rozwojem folwarku rozumianego jako dominujący sposób produkcji, a zarazem formuła integrująca szlachtę ze stanem chłopskim. Hryniewicz twierdzi, że zmiany te miały wysoce dysfunkcjonalny charakter. Folwark, w odtworzonym kontekście, był synonimem kultury kolektywistycznej, będącej „,...] na ogół familocentryczną albo klanową i dążącą do ograniczenia aktywności pozarodzinnej na rzecz kultywowania więzi rodzinnej"6. Jako wzorzec dobrego życia, utrudniał dostęp do zdobyczy cywilizacyjnych będących pochodną „modelu racjonalności kartezjańskiej”, upowszechnianego $\mathrm{w}$ państwach zachodnich. Szacowanie strat - nie tylko strat ekonomicznych - możliwe jest zatem przez porównanie jednego z drugim. Zdaniem Hryniewicza „Ugruntowanie się zasad racjonalnego ustalania celów jako wzoru kulturowego jest równoznaczne z zaistnieniem powszechnego przekonania, że ocena słuszności argumentów opiera się na kilku powszechnie znanych i stosowanych zasadach logicznych. Jeżeli znamy te zasady i wiemy, że inni się do nich stosują, to zachowania innych ludzi stają się przewidywalne nie tylko $\mathrm{w}$ wąskim zakresie interesu wspólnego, ale także w odniesieniu do szerszego spektrum rzeczywistości społecznej. [...] Etyczny indywidualizm polega na przyznawaniu pierwszeństwa zobowiązaniom zawartym osobiście nad zobowiązaniami wynikającymi z przynależności grupowej, które nie istniały w momencie zawierania umowy, a które potencjalnie mogą się pojawić. Przeciwieństwem jest kolektywizm, w którym zobowiązania osobnika wobec grupy dominują nad wszystkim innymi zawartymi przez niego umowami"7.

\footnotetext{
${ }^{5}$ Choć owe wzorce Hryniewicz nazywa archetypami, to w odróżnieniu od Junga nadaje im „socjologiczne” znaczenie. „Do zachowań organizacyjnych - wyjaśnia autor Stosunków pracy... - wprowadziła je Monika Kostera, używając ich jako jednego z kluczowych pojęć postmodernistycznej metodologii zastosowanej do wyjaśnienia zachowań menedżerów, w której archetyp funkcjonuje jako 'główna funkcjonalna metafora' [...] dziedziczona w postaci uogólnionego wzoru zachowań jako synteza wcześniejszych przeżyć”, J.T. Hryniewicz, Stosunki pracy..., s. 21; por. J.T. Hryniewicz, Polityczny i kulturowy kontekst rozwoju gospodarczego, Wydawnictwo Naukowe Scholar, Warszawa 2004, s. 141-150.

6 J.T. Hryniewicz, Stosunki pracy..., s. 27.

7 Ibidem, s. 27-28.
} 
Za pomocą powyższego rozróżnienia Hryniewicz formułuje problem badawczy. $Z$ jednej strony etyczny indywidualizm przedstawia jako jedną z tych "osobliwości kultury europejskiej”, dzięki którym stworzone zostały "instytucje demokratyczne oraz gospodarka rynkowa" 8 . Z drugiej strony przyczyny niesprawności mechanizmów politycznych i gospodarczych w naszym kręgu kulturowym tłumaczy ograniczeniami wynikającymi z upowszechnienia się kolektywistycznych form współdziałania. Owszem, Hryniewicz nie traci wiary $\mathrm{w}$ możliwość poprawy stosunków bieżących. Wyzwanie to jednak odnosi do zatorów obecnych w myśleniu zbiorowym pomimo zmian, jakie przyniosła najpierw gospodarka kapitalistyczna, później czas PRL-u, a na koniec Jesień Ludów 1989 roku. W sensie mentalnym, przekonuje Hryniewicz, wciąż jesteśmy mieszkańcami folwarku. Skojarzenie tej tezy z doświadczeniem powszednim zmusza do pokory. Wiele jest w naszym życiu zbiorowym zaszłości stawiających pod znakiem zapytania deklaracje polityków o budowaniu „drugiej Japonii” bądź o odporności "zielonej wyspy" na skutki kryzysu światowego. W politycznym kontekście folwark jako symbol wydaje się właściwie użyty. Niepokój natomiast budzą jego zastosowania historyczne i kulturowe.

O miarodajności wiedzy o specyfice życia gospodarczego decydować ma sposób jej pozyskiwania. Hryniewicz skupia się na procesach długiego trwania. Ta deklaracja oznacza wybór metody, której celem jest odróżnienie epizodów (na przykład wydarzeń politycznych) od zmian kształtujących bieg dziejów ${ }^{9}$. Wskazany wyróżnik pomaga $\mathrm{w}$ eliminowaniu interpretacyjnych dowolności. Uchodzący za jego twórcę, Fernand Braudel wymienia cztery struktury określające kierunek i dynamikę procesów historycznych. Są nimi: środowisko geograficzne, struktura społeczna, struktura ekonomiczna oraz mentalność zbiorowa ${ }^{10}$. Kierując się tym rozróżnieniem, należy przyjąć, że zamierzeniem (głównym) Hryniewicza jest odtworzenie czwartej struktury - wykazanie, iż nawyki mentalne ukształtowane w odległej perspektywie czasowej determinują zachowanie człowieka współczesnego.

Ocena propozycji Hryniewicza obejmuje dwa zadania. Pierwszym z nich jest sprawdzenie, czy reprodukcja wzorców folwarcznych może być uznana za proces długiego trwania. Aby się o tym przekonać, trzeba odtworzyć (najlepiej kwantytatywnie) wzorce prototypowe, a następnie odnaleźć ich odpowiedniki w kolejnych stadiach dziejów. Drugim zadaniem jest weryfi-

\footnotetext{
8 Ibidem, s. 23.

${ }^{9}$ W. Wrzosek, Idea kultury materialnej F. Braudela, „Kwartalnik Historii Kultury Materialnej" 1994, nr 2, s. 167-172.

${ }^{10}$ F. Braudel, Gramatyka cywilizacji, przeł. H. Igalson-Tygielska, Oficyna Naukowa, Warszawa 2006, s. 55.
} 
kacja założenia o użyteczności (prawomocności) zaproponowanego kryterium. Zachowania gospodarcze kształtuje nie tylko to, co trwa długo, lecz także czynniki będące następstwem społecznej zmiany11. Możliwy jest wariant, w którym jedno łączy się z drugim. Ewoluujące wyobrażenia o tym, co było, są wówczas reakcją na - odkrywane w nowych okolicznościach - dysfunkcje społeczne bądź gospodarcze. Wyrażona wątpliwość ma znaczenie. Nie wolno zapominać o tym, że nazbyt restrykcyjna selekcja komponentów kulturowej diagnozy przekłada się na jej jakość.

Zapowiedziane czynności poprzedza niejasność odnośnie do przypisywanego folwarkowi destrukcyjnego wpływu na gospodarkę Rzeczypospolitej Obojga Narodów. W połączeniu z twierdzeniem, iż folwark był dominującym sposobem produkcji - czy przynajmniej dominującym schematem organizacyjnym - ocena ta pozostaje $\mathrm{w}$ konflikcie $\mathrm{z}$ ustaleniami dotyczącymi sprawności gospodarczej i militarnej tamtego państwa. W największym skrócie, nostalgia Polaków za czasami opisywanymi przez Sienkiewicza nie bierze się znikąd. Podobne kontrowersje wywołuje zestawienie indywidualizmu pochodzenia zachodniego (opartego na kartezjańskiej idei racjonalności) z polskim kolektywizmem, ograniczającym inicjatywę gospodarczą do (metafizycznego) postulatu ochrony więzi grupowych. Indywidualizm, skojarzony przez Hryniewicza z poglądami Kartezjusza, ma równie niewiele wspólnego z historią Francji (do 1789 roku będącą monarchią absolutną), co z jej sytuacją obecną. Francis Fukuyama, przedstawiając Francuzów jako spadkobierców kultury feudalnej, jakkolwiek w sposób niedosłowny, posługuje się argumentem długiego trwania ${ }^{12}$. W przeciwieństwie do nich Polacy w XV i XVI wieku tworzą zręby nowego ustroju politycznego, nazywanego demokracją szlachecką ${ }^{13}$.

Wyrażone obiekcje nie powinny przesłaniać - kluczowego w związku z wyborem metody - problemu podobieństw strukturalnych pomiędzy tym, co było, a tym, co jest. Dla porządku należy wyjaśnić, że podobieństwa strukturalne obejmują kontekst społeczny i gospodarczy, w jakim powielane

\footnotetext{
11 Spór o treści wypełniające społeczną podświadomość podzielił niegdyś H. Marcusego i E. Fromma. Marcuse zarzucił Frommowi nadmierną dowolność w selekcji przekonań determinujących zachowanie społecznego aktora. Adaptując Freudowski schemat świadomości, skupił się na tym, co w antropologicznym (kulturowym, historycznym) sensie powszechne i trwałe. Tymczasem, oddając sprawiedliwość Frommowi, zapytać trzeba, cóż począć z „autorytetami anonimowymi" - wzorcami obecnymi w myśleniu zbiorowym od niedawna, bądź tymi, których kształt ulega zmianom wykluczającym ich opis w kategoriach ciągłości. Wydaje się, że również one zasługują na uwagę badacza zmierzającego do odtworzenia możliwie pełnego obrazu kultury.

12 F. Fukuyama, Zaufanie. Kapitat spoteczny a droga do dobrobytu, przeł. A. Śliwa, L. Śliwa, PWN, Warszawa 1997, s. 136-151.

13 S. Grzybowski, Dzieje Polski i Litwy (1506-1648), Świat Książki, Kraków 2000.
} 
zostały wzorce pochodzenia historycznego. Zakłada się tu, iż reprodukcja treści mentalnych dokonywała się pomimo wielości różnic uzasadniających wybór alternatywnych reguł postępowania. Wiele przecież wydarzyło się od czasów Rzeczypospolitej Obojga Narodów. Warte podkreślenia jest to, że zmiany, o których mowa, dokonywały się w obrębie trzech zaborów. Oznaczało to - trwająca ponad wiek - przynależność poszczególnych regionów Polski do odrębnych organizmów politycznych i wspólnot kulturowych. Hipoteza badawcza obejmuje następnie dwudziestolecie międzywojenne, epokę PRL, a wreszcie okres po 1989 roku.

Hryniewicz wykazuje analogię pomiędzy wymienionymi etapami dziejów. Definiując przedmiot badania, skupia się na tym, że: „Folwarczna kultura organizacyjna doprowadziła do utrwalenia dwóch odmiennych typów zachowań pracowników i kierownictwa folwarku. Po stronie właścicieli-kierowników mieliśmy nieskrępowaną władzę i świadomość decyzyjności nieograniczonej przepisami, po stronie chłopów wykształcił się etos wymuszonego lub zinternalizowanego posłuszeństwa $\mathrm{w}$ połączeniu $\mathrm{z}$ brakiem poczucia odpowiedzialności i zapotrzebowaniem na szczegółowe instrukcje w pracy i opiekę kierownika poza pracą. [...] Wyrazem trwałości tego etosu w środowisku chłopskim były dość częste w XVIII w. negatywne reakcje chłopów na propozycje zniesienia pańszczyzny i poszerzenia gospodarstw chłopskich. [...] Z kolei właściciel folwarku zwiększał swą władzę nad chłopem i zmniejszał wysiłek psychiczny oraz intelektualny towarzyszący kierowaniu. [...] Dość często, w myśl zaleceń ówczesnych podręczników, mieszkańcy dworu poczuwali się do odpowiedzialności za stan ducha wsi"14.

Cechami charakterystycznymi folwarku, zgodnie $\mathrm{z}$ podanym opisem, były zatem: (1) nieskrępowana władza i świadomość decyzyjności właściciela, (2) zinternalizowane posłuszeństwo chłopa połączone $z$ zapotrzebowaniem na szczegółowe instrukcje i opiekę pana oraz (3) poczucie odpowiedzialności mieszkańców dworu za stan ducha wsi. Tezę o trwałości podanego wzorca organizacyjnego Hryniewicz objaśnia za pomocą kilku argumentów. Najpierw zestawia definicję folwarku $\mathrm{z}$ obrazem PRL-owskiego przedsiębiorstwa. Użyteczność dokonanego porównania ma potwierdzać to, że „Socjalistyczny zakład pracy, podobnie jak folwark, oddzielał pracownika od państwa. Zakłady nie pełniły co prawda funkcji sądowniczych, ale miały uprawnienia administracji publicznej w sprawach socjalno-bytowych i pełniły istotne funkcje polityczne. [...] W efekcie - socjalistyczne zakłady pracy były bardziej podobne do folwarków niż do typowych przedsiębiorstw kapitalistycznych"15.

14 J.T. Hryniewicz, Stosunki pracy..., s. 33.

15 Ibidem, s. 37. 
Uzupełniając historyczną diagnozę, Hryniewicz przedstawia współczesnych przedsiębiorców polskich - działających w realiach rynkowych - jako spadkobierców wciąż tych samych wzorców organizacyjnych. Przytacza przykład właściciela firmy zwalniającej pracowników na chybił trafił po to, by w pozostałej części załogi wzbudzić (bądź spotęgować) strach przed utratą pracy. W procesie decyzyjnym nie ma znaczenia ani los zwolnionych ludzi, ani skala zwolnień. Liczy się tylko efekt w postaci nieskrępowanej władzy prezesa-satrapy ${ }^{16}$. Równie dwuznaczne jest stosowane przez Hryniewicza kryterium sprawiedliwości. Oczekiwania wobec zatrudnionych także te wynikające $\mathrm{z}$ umowy o pracę - mają się nijak do gwarancji, jakie daje im jako organizator nominalnie wspólnego przedsięwzięcia gospodarczego.

Opowiedziana historia mówi wiele o mentalności polskich menedżerów. (Mówi o nich wiele, nawet jeśli stanowi wyrywkowe ujęcie reguł sterujących życiem gospodarczym w naszym kraju). Podobnie jak charakterystyka PRL-owskiego zakładu pracy, nie daje jednak podstaw ku temu, by kojarzyć ją ze staropolskim folwarkiem. Owszem, pomiędzy wymienionymi perspektywami zachodzą podobieństwa. Niestety, nie są to podobieństwa strukturalne. W przypadku PRL-owskiego zakładu pracy uwzględnienia wymagają determinanty branżowe, polityczne czy prawne ograniczające jego włodarzy $\mathrm{w}$ ich poczynaniach. Stwierdzenie, że ówczesne przedsiębiorstwa „nie pełniły funkcji sądowniczych", zdecydowanie nie wystarcza. Chodzi nie tylko o swobodne dysponowanie pracownikiem, lecz - przede wszystkim o wolność kierownictwa od ocen zewnętrznych i podążających w ślad za nimi kar. "Szlachcic na zagrodzie równy wojewodzie" - mówi staropolskie przysłowie (pierwsza cecha definicyjna folwarku). Streszcza ono zwłaszcza te przywileje, które nadał szlachcie Zygmunt I Stary w latach 1518 i 1532. W odróżnieniu od właściciela folwarku PRL-owski dyrektor miał się czego obawiać. Do rangi symbolu urasta przypadek Stanisława Wawrzeckiego skazanego na karę śmierci (w 1965 r.) w tzw. „aferze mięsnej”. Nominalnie Wawrzecki został ukarany za przestępstwa gospodarcze. Faktycznie wyrok wydali jego wysoko postawieni wspólnicy, zamykający w ten sposób usta potencjalnemu denuncjatorowi. Tamta zbrodnia sądowa była możliwa, ponieważ PRL-owska zagroda nie zrównywała „szlachcica” $\mathrm{z}$ „wojewodą”.

Podobnie chybiają celu analogie współczesne. Chybiają celu, gdyż nie uwzględniają ogółu cech składających się na folwarczny styl kierowania organizacją gospodarczą. Prezes-satrapa z podanego przykładu nie jest uczestnikiem przedsięwzięcia trwale wiążącego go z tymi, którym daje pra-

16 Ibidem, s. 39. 
cę (druga i trzecia cecha definicyjna folwarku). Nie może nim być, ponieważ przeszkadza mu „świadomość decyzyjności nieograniczonej przepisami”. Jego chłopi - parafrazując Hryniewicza - na pewno nie mieliby nic przeciwko temu, by "znieść pańszczyznę i poszerzyć ich gospodarstwa”. Są ofiarami przemocy niemającej nic wspólnego $\mathrm{z},[\ldots]$ etosem wymuszonego lub zinternalizowanego posłuszeństwa [występującego - dop. P.R.] w połączeniu z brakiem poczucia odpowiedzialności i zapotrzebowaniem na szczegółowe instrukcje w pracy i opiekę kierownika poza pracą [...]". Zamiast więzi folwarcznych pojawia się u nich myśl o „obrotowych drzwiach”, przez które $\mathrm{w}$ przypadku poprawy sytuacji na rynku pracy - mogliby uciec z miejsca postrzeganego przez nich jako niepewne i nieprzyjazne.

\section{WZORY KULTURY - INTERPRETACJA, TRWAŁOŚĆ}

Zestawienie wspomnień o gospodarczym współdziałaniu z praktykami konfrontacyjnymi powoduje, że badania mentalności folwarcznej zmieniają kierunek. Miejsce definicji obejmującej jej cechy dystynktywne zajmuje pytanie o tożsamość grupową skonfliktowanych aktorów. Rozchodzenie się ich perspektyw poznawczych rodzi obawy dotyczące percepcji, transmisji, a wreszcie znaczenia nadawanego wzorom kultury przez (podzielonych) uczestników życia gospodarczego ${ }^{17}$. Na czoło wybija się niezgodność znaczeń, wcześniej uchodzących za jednorodne bądź bliskoznaczne - niezgodność świadcząca o tym, że dawna wspólnota interpretacji przestała istnieć. Jej członkowie opuścili folwark zdefiniowany jako miejsce integracji różnych stanów społecznych, efekt możliwy do osiągnięcia w wyniku korelacji władzy z subiektywnie pojętą odpowiedzialnością za słabszych. Ujmując rzecz lapidarnie, staropolskie wzorce życia gospodarczego, podobnie jak ascetyczne standardy zarządcze odtworzone przez Maxa Webera w Etyce protestanckiej...18, wyparte zostały przez zasady wolnego rynku oraz - stanowiącą ich przeciwwagę - Marksowską tezę o przewadze pracy nad kapitałem.

Trudno przecenić wartość wiedzy o społecznej zmianie w badaniu procesów długiego trwania. Bez dostępu do niej nie jest możliwe wyjaśnienie, jak przez sito spraw aktualnych (i zróżnicowanej reakcji na nie) przebiły się wzorce historyczne, za czyją sprawą zachowały swoją trwałość oraz jakie znaczenie nadaje im ich współczesny użytkownik. Pomocne $w$ badaniach dotyczących folwarku wydają się ustalenia dotyczące własności środków

17 Por. R.K. Merton, op. cit., s. 103-104; R. Putnam, op. cit., s. 168.

18 M. Weber, Etyka protestancka a duch kapitalizmu, Aletheia, Warszawa 2011. 
produkcji (nie tylko własności ziemi) oraz związków łączących gospodarza z jego społecznym otoczeniem. Hryniewicz nie uchyla się przed odpowiedzią na zadane pytania. Przyczyną, dla której wzorce folwarczne są nadal żywe, była - jego zdaniem - rola, jaką odegrały w podjętej przez intelektualistów (przede wszystkim przez ludzi pióra) krytyce rzeczywistości rynkowej. Hryniewicz objaśnia tę zależność w następujący sposób: „Historyczny transfer stosunków folwarcznych do współczesności był ułatwiony dzięki antykapitalistycznemu nastawieniu kultury literackiej. Dzieła klasyków polskiej literatury, nawet jeśli zawierają jednocześnie opisy fabryki i folwarku, ten drugi zawsze przedstawiają w lepszym świetle, czasami jako raj utracony (np. Wł. Reymont, Ziemia obiecana) albo ostoję polskości czy ideał urządzenia stosunków społecznych z panem, który wybacza, i panią domu, która od czasu do czasu czymś chłopów obdarowuje. Kultura folwarczna ukształtowała nie tylko styl kierowania, ale także sposób reagowania na polecenia. Ukształtowała zatem w równym stopniu kierujących co pracowników"19.

Jeśli właściwie rozumiem wyrażony pogląd, folwark w narracjach XIX-wiecznych stał się aksjologicznym punktem odniesienia, kryterium oceny tego, co jest. Tyle tylko, że kryterium pseudohistorycznym. Odrzucenie drapieżnego kapitalizmu dokonywało się poprzez jego porównanie ze wspomnieniem świata, w którym cele gospodarcze spontanicznie komponowały się z potrzebami społecznymi (obejmującymi oczekiwania różnych stanów) ${ }^{20}$. Takie postępowanie było wyrazem nostalgii ludzi za „rajem utraconym". Drugorzędne znaczenie miała wierność faktom, czy choćby ich znajomość. Decydowało przekonanie, iż „sprawy nie toczą się właściwym torem". Tę zależność objaśnia Marks spierający się z Feuerbachem o społeczne funkcje religii. Marks nie kwestionuje tego, że religia jest przejawem świadomości fałszywej. Nie zgadza się jednak ze swoim adwersarzem redukującym ją do treści podlegających rugowaniu. Owo rugowanie, wyjaśnia Marks, możliwe jest tylko wtedy, gdy jest następstwem kształtowania się świadomości klasowej proletariatu. Warunkiem koniecznym tego procesu jest umiejętność (krytycznej) oceny wydarzeń teraźniejszych przez ich uczestników. Wobec braku kryterium historycznego, możliwego do odtworzenia wyłącznie przez wyemancypowaną klasę społeczną, dobre jest każde inne ${ }^{21}$.

19 J.T. Hryniewicz, Stosunki pracy..., s. 35.

20 Por. G. Sroczyński, Folwark polski, http://wyborcza.pl/magazyn/1,137770,15785648, Folwark_polski.html [dostęp: 12.04.2014].

${ }^{21}$ K. Marks, Tezy o Feuerbachu, przeł. S. Filmus, [w:] K. Marks, F. Engels, Dzieła, t. 3, Książka i Wiedza, Warszawa 1961, s. 7-8. 
Tropem Marksa podążają socjolodzy wiedzy, koncentrujący się na problemie partykularnych uwikłań społecznego aktora (uwikłań kształtujących jego sposób widzenia spraw wspólnych ${ }^{22}$. Na przykład Peter Berger przypomina o naturalnej, tzn. uzasadnionej interesem grupowym, skłonności intelektualistów do sytuowania się po lewej stronie sceny politycznej23. Atrakcyjność lewicowych narracji, w tym autorytet ich wytwórców postrzeganych jako zbiorowy depozytariusz kapitału kulturowego, wyjaśnia, jak wzory postępowania odzwierciedlające $\mathrm{w}$ punkcie wyjścia mentalność określonych grup społecznych awansowały do rangi mitu reprezentatywnego dla całej formacji społecznej.

W zaproponowanej optyce miejsce struktur długiego trwania zajmuje różnica, w przypadku depozytariusza wzorów folwarcznych przejawiająca się utratą jego zaufania do organizatorów życia politycznego i gospodarczego. Z podobieństw strukturalnych akcent przeniesiony zostaje na podobieństwa akcydentalne zawierające się we wspomnieniu "czasu szczęsnego". Nie znajduje potwierdzenia domniemanie, że jesteśmy - wciąż tymi samymi mieszkańcami folwarku. Coś jednak sprawia, iż nie chcemy się rozstać z wyobrażeniami „dobrego gospodarowania” pochodzenia staropolskiego. Czy owo przywiązanie jest wyrazem mentalnego zapóźnienia Polaków? Obrona tej tezy wymagałaby uwzględnienia zmieniających się okoliczności. Problemem głównym są przeszkody w postaci gospodarczych artefaktów niemających nic wspólnego z folwarkiem. Warto nawiązać do XIX-wiecznej historii polskiego kapitalizmu, w szczególności do dokonań przedsiębiorców-patriotów, między innymi tych pochodzących z Wielkopolski, a na tym nie kończy się lista zdarzeń interpretacyjnie kłopotliwych. To zaś uzasadnia wybór innego wyjaśnienia fenomenu folwarku.

W skorygowanym ujęciu folwark przestaje funkcjonować jako wewnętrzne ograniczenie uczestnika życia gospodarczego. Staje się alegorią stanu pożądanego, (mentalną) przeciwwagą dla dysfunkcji zawierających się w strukturze społecznej i ekonomicznej24. Korespondują one z cechami definicyjnymi folwarku podanymi przez Hryniewicza. Po pierwsze, „świadomość decyzyjności" dawnego właściciela folwarku przybiera kształt ma-

22 P. Bourdieu, Zaproszenie do socjologii refleksyjnej, przeł. A. Sawisz, Oficyna Wydawnicza, Warszawa 2001, s. 162-163; K. Mannheim, Ideologia i utopia, przeł. J. Miziński, Wydawnictwo Test, Lublin 1992.

23 P.L. Berger, Rewolucja kapitalistyczna. Pięćdziesiąt tez o dobrobycie, równości $i$ wolności, przeł. Z. Simbierowicz, Oficyna Naukowa, Warszawa 1995, s. 130, 132, 134-135, por. s. 317-339.

${ }^{24}$ Drugorzędne znaczenie ma wybór metody umożliwiającej ich interpretację. Hipoteza o istnieniu wzorca kultury w równym stopniu poprzedza, co kończy gromadzenie danych cząstkowych. Kieruje uwagę badacza na to, co warte jego uwagi (jako przedstawiciela określonej dziedziny wiedzy), a zarazem pomaga mu w wyciągnięciu wniosków z tego, co ustalił. 
rzenia o bezwzględnej ochronie własności, zwłaszcza domu oraz środków produkcji ${ }^{25}$. Polski przedsiębiorca, od niepamiętnych czasów, doświadcza niepewności dotyczącej tego, co ma. Nie chodzi o samo posiadanie rzeczy, lecz o prawo dysponowania nimi. Zaborowe konfiskaty majątków ziemskich - w pamięci zbiorowej - zadziwiająco dobrze współgrają z reformą rolną (1944 r.) i innymi ustawami antywłasnościowymi przyjętymi we wczesnym PRL-u. Niestety, w tym względzie III RP zrobiła mniej, niż można się było spodziewać. Do rangi symbolu urasta decyzja o przejęciu przez państwo składek gromadzonych przez obywateli $\mathrm{w}$ otwartych funduszach emerytalnych (2013 r.). Mniejsza o dokonaną naprędce wykładnię ustawy emerytalnej z 1999 roku. Z wyjaśnień złożonych przez Donalda Tuska wynika, że elity władzy (z Jerzym Buzkiem na czele) przez czternaście lat mamiły społeczeństwo obietnicą bezpieczeństwa środków rzekomo wyprowadzonych poza państwowy obieg26. Tak - między innymi - reprodukowany jest wzór kultury nakazujący ostrożność w kontaktach „wywłaszczonych mieszkańców folwarku" $\mathrm{z}$ ich politycznym opiekunem.

Po drugie, kulturowym ekwiwalentem „[...] zinternalizowanego posłuszeństwa chłopa połączonego z zapotrzebowaniem na [...] opiekę pana" jest postulat bezpieczeństwa socjalnego i zawodowego niższych warstw społecznych. Nie warto spierać się o jego pochodzenie. Brak zaufania do gospodarczych partnerów wpływa na sposób rozumienia procesów dziejowych. I vice versa, owe procesy w oczywisty sposób wyzwalają (względnie pogłębiają) nieufność. W XIX wieku implementacja reguł wolnego rynku napotkała przeszkodę w postaci doświadczenia nędzy opisanego - między innymi przez literatów. XX-wieczna próba naprawy stosunków społecznych przez państwo socjalistyczne, nie tylko w polskich realiach, zakończyła się buntem robotników. Hryniewicz głosi, że ich aksjologicznym punktem odniesienia był folwark rozumiany jako miejsce, którego ich chłopscy antenaci nie chcieli opuszczać nawet wtedy, gdy byli kuszeni propozycją uwłaszczenia. Wynika $\mathrm{z}$ tego, że quasi-historyczne kryterium pomagało uważnym obserwatorom życia społecznego rozpoznać (przynajmniej te) pułapki systemowe, w które wpadli.

Po trzecie, „poczucie odpowiedzialności mieszkańców dworu za stan ducha wsi" upodabnia się do zasady integracji realizowanej pod przewod-

25 Por. H. de Soto, Tajemnica kapitatu. Dlaczego kapitalizm triumfuje na Zachodzie, a zawodzi gdzie indziej, przeł. S. Czarnik, Fijorr Publishing, Warszawa 2003.

${ }^{26}$ Nie mniej dziwaczna jest sytuacja samych funduszy, na mocy nowych regulacji prawnych padających ofiarą niechętnych im polityków. Czymże innym są ograniczenia dotyczące inwestowania przez OFE w obligacje skarbu państwa albo emitowania reklam, jeśli nie szykanami pozostającymi w wątpliwym związku z zasadą wolności gospodarczej? 
nictwem gospodarczych i politycznych liderów. Idea społecznego zbliżenia, podobnie jak postulat bezpieczeństwa socjalnego, pojawia się $\mathrm{w}$ dominujących narracjach politycznych naszych czasów. Niestety, to nie przesądza o niczym. Pogarszająca się sytuacja gospodarcza członków Unii Europejskiej zmusiła ich do szukania rezerw w kieszeniach własnych obywateli. Miejsce obietnic państwa socjalnego zajęły uchylenia podobne do tych dokonywanych w Polsce w związku z zamiarem podniesienia wieku emerytalnego czy likwidacji (ewentualnie: ograniczenia wpływów) OFE27. „Stan ducha wsi” będący następstwem podobnych poczynań jest łatwy do przewidzenia. Przywództwo pozbawione moralnej sankcji staje się przedmiotem krytyki zwłaszcza tych, którzy nie porzucili nadziei na obecność $\mathrm{w}$ ich otoczeniu „odpowiedzialnych mieszkańców dworu”28.

W zaproponowanej formule wyjaśniającej miejsce „archetypu folwarcznego" zajmują wzorce postępowania: (1) nakazujące gospodarzowi ostrożność w kontaktach z państwem; (2) antagonizujące stosunki pomiędzy pracodawcą i pracobiorcą; (3) wzmagające obawy obywatela w odniesieniu do politycznej i moralnej - wiarygodności innych uczestników sfery publicznej. Gwoli ścisłości należy dodać, że tezę o trwałości odtworzonych struktur powinny uzupełniać badania. Wobec ich braku ograniczę się do wskazania tego, co stanowi ich zdroworozsądkową przesłankę. Mam na myśli dysfunkcje tyleż osłabiające aktywność uczestników życia gospodarczego, co skłaniające ich do oporu uzasadnionego wspomnieniem lepszej (stabilniejszej) przeszłości.

\section{WNIOSKI}

Badania dotyczące wzorców kultury gospodarczej, inspirowane propozycją J. Hryniewicza, wiodą do następujących wniosków. Mentalność fol-

${ }_{27}$ P. Rotengruber, Nauka wobec kryzysu gospodarczego, nauka wobec kryzysu zaufania, [w:] Ekonomiczne i etyczne aspekty kryzysu gospodarczego, red. R. Kamiński, J. Sójka, PTE, Poznań 2013, s. 161-173.

${ }^{28}$ Podobne stanowisko zajmuje Fukuyama zwracający uwagę na to, że „Niemożność poszerzenia kręgu zaufania poza rodzinę i przyjaciół może mieć korzenie religijne, ale może też być efektem złych rządów. Klarowne rządy prawa tworzą podstawy dla wzajemnego zaufania pomiędzy obcymi sobie ludźmi. Nie wszędzie jednak istnieje takie prawo. Niektórym państwom nie udało się zapewnić skutecznego przestrzegania praw własności ani zagwarantować bezpieczeństwa publicznego, inne okazały się arbitralne i drapieżne w sposobach ściągania podatków i kontrolowania społeczeństwa. W tych warunkach rodzina staje się bezpieczną przystanią, zamkniętą strefą, w której można być względnie pewnym rzetelności innych", F. Fukuyama, Wielki Wstrzas, przeł. H. Komorowska, K. Dobrosz, Politeja, Warszawa 2000, s. 222. 
warczna, wbrew ustaleniom tego autora, nie może być uznana za strukturę długiego trwania. Podobieństwa, za pomocą których Hryniewicz uzasadnia swój pogląd, nie są podobieństwami strukturalnymi. Obrazy uznane za reprezentatywne dla polskiej historii gospodarczej różnią się zawartością obejmującą cechy definicyjne folwarku. Dyrektor socjalistycznego zakładu pracy z całą pewnością nie był sobiepanem. Podobnie pracobiorcy, ofiary współczesnego przedsiębiorcy-właściciela, nie widzą w nim kogoś, komu chciałyby powierzyć swój los. Nie ma mowy o reprodukcji tych samych struktur mentalnych. Miarodajne stają się raczej różnice poznawcze potęgujące napięcia pomiędzy zwaśnionymi grupami. Owszem, mentalność folwarczna dzieliła chłopów i mieszkańców dworu. Podziały te jednak niwelowane były - przez obie strony - $\mathrm{w}$ imię łączących je interesów (zbieżne były ich cele życiowe).

Tymczasem problem niepodobieństw strukturalnych - w perspektywie badań nad kulturą - nie unieważnia pytań: (1) o bogactwo wzorców kultury, również tych pozbawionych (historycznie potwierdzonej) cechy długiego trwania, (2) o aktualność mitu folwarku oraz (3) o jego związki z innymi determinantami kulturowymi. Bez względu na to, jakim wyobrażeniem folwarku posługiwały się kolejne pokolenia Polaków, zasadne jest domniemanie, że pozostaje on ich aksjologicznym punktem odniesienia, miarą, za pomocą której oceniają to, czego doświadczają. Sformułowana hipoteza koresponduje z cechami definicyjnymi folwarku, takimi jak: wolność pracodawcy, bezpieczeństwo pracobiorcy czy wzór organizacyjny minimalizujący ryzyko konfliktów. Wymienione cechy przełożone na język socjologii wiedzy przybierają kształt przekonań o obecności przeszkód ograniczających pole manewru gospodarczym interlokutorom. Niebagatelne znaczenie ma czas, w jakim posługują się oni (quasi-)folwarczną miarą. Przywiązanie do niej może sugerować, iż mamy do czynienia z dysfunkcjami życia publicznego zasadnie aspirującymi do miana struktur długiego trwania. Oznacza to powrót do punktu wyjścia. Aby bowiem przekonać się, czym są owe dysfunkcje, trzeba powtórzyć badanie wzorców kultury gospodarczej.

\section{BIBLIOGRAFIA}

Berger P.L., Rewolucja kapitalistyczna. Pięćdziesiąt tez o dobrobycie, równości i wolności, przeł. Z. Simbierowicz, Oficyna Naukowa, Warszawa 1995.

Bourdieu P., Zaproszenie do socjologii refleksyjnej, przeł. A. Sawisz, Oficyna Wydawnicza, Warszawa 2001.

Braudel F., Gramatyka cywilizacji, przeł. H. Igalson-Tygielska, Oficyna Naukowa, Warszawa 2006. 
Fukuyama F., Wielki Wstrząs, przeł. H. Komorowska, K. Dobrosz, Politeja, Warszawa 2000.

Fukuyama F., Zaufanie. Kapitat społeczny a droga do dobrobytu, przeł. A. Śliwa, L. Śliwa, PWN, Warszawa 1997.

Grzybowski S., Dzieje Polski i Litwy (1506-1648), Świat Książki, Kraków 2000.

Hankiss E., Pułapki społeczne, przeł. T. Kulisiewicz, Wiedza Powszechna, Warszawa 1986.

Hryniewicz J.T., Polityczny $i$ kulturowy kontekst rozwoju gospodarczego, Wydawnictwo Naukowe Scholar, Warszawa 2004.

Hryniewicz J.T., Stosunki pracy w polskich organizacjach, Wydawnictwo Naukowe Scholar, Warszawa 2007.

Mannheim K., Ideologia i utopia, przeł. J. Miziński, Wydawnictwo Test, Lublin 1992.

Marks K., Tezy o Feuerbachu, przeł. S. Filmus, [w:] K. Marks, F. Engels, Dzieła, t. 3, Książka i Wiedza, Warszawa 1961.

Merton R.K., Teoria socjologiczna i struktura społeczna, przeł. E. Morawska, J. Wertenstein-Żuławski, PWN, Warszawa 1982.

Putnam R., The Prosperous Community: Social Capital and Public Life, TAP, Spring 1993.

Rotengruber P., Nauka wobec kryzysu gospodarczego, nauka wobec kryzysu zaufania, [w:] Ekonomiczne i etyczne aspekty kryzysu gospodarczego, red. R. Kamiński, J. Sójka, PTE, Poznań 2013.

de Soto H., Tajemnica kapitatu. Dlaczego kapitalizm triumfuje na Zachodzie, a zawodzi gdzie indziej, przeł. S. Czarnik, Fijorr Publishing, Warszawa 2003.

Sroczyński G., Folwark polski, http://wyborcza.pl/magazyn/1,137770,15785648,Folwark _polski.html [dostęp: 12.04.2014].

Weber M., Etyka protestancka a duch kapitalizmu, Aletheia, Warszawa 2011.

Wocial J., Znanieckiego filozofia wartości, [w:] F. Znaniecki, Pisma filozoficzne, t. 1, przeł. J. Wocial, PWN, Warszawa 1987.

Wrzosek W., Idea kultury materialnej F. Braudela, „Kwartalnik Historii Kultury Materialnej" 1994, nr 2.

Znaniecki F., Pisma filozoficzne, t. 1, przeł. J. Wocial, PWN, Warszawa 1987. 